Quarterly Journal of Engineering Geology and Hydrogeology

\title{
A plane slide that occurred during construction of a national expressway in Chongqing, SW China
}

Z.Q. Yue and C.F. Lee

Quarterly Journal of Engineering Geology and Hydrogeology 2002; v. 35; p. 309-316 doi:10.1144/1470-9236/01004

Email alerting click here to receive free email alerts when new articles cite this article

service

Permission

click here to seek permission to re-use all or part of this article

request

Subscribe

click here to subscribe to Quarterly Journal of Engineering Geology and Hydrogeology or the Lyell Collection

\section{Notes}

Downloaded by University of Hong Kong Libraries on 8 August 2007 


\title{
A plane slide that occurred during construction of a national expressway in Chongqing, SW China
}

\author{
Z.Q. Yue \& C.F. Lee \\ Department of Civil Engineering, The University of Hong Kong, Pokfulam Road, Hong Kong, China
}

\begin{abstract}
Wis paper presents a case study of a major landslide that occurred during the construction of a national expressway in Chongqing, southwestern China. The landslide was a typical plane failure associated with steep cutting in weathered mudstone and sandstone. The weathered mudstone block slipped down along the bedding interface of the mudstone and sandstone and formed an open gap that measured some 6 to $8 \mathrm{~m}$ high, by 2 to $7 \mathrm{~m}$ wide and $53 \mathrm{~m}$ long in the hillside slope. This study referred that the landslide was caused by the combined effect of the following factors: (a) an unsupported high and steep cutting in weathered mudstone; (b) an exposed bedding interface between the incompetent weathered mudstone and the competent sandstone that daylights within the cut slope; (c) the mudstone and sandstone bedding interface as a pre-existing folding tectonic shear plane of low shear strength; and (d) the possible presence of a ground water table in the weathered mudstone perched on the relative impervious sandstone bedding surface. The case study highlights the importance of engineering geological mapping during and immediately after the formation of a new cut slope. It also emphasises the importance of identification of the pre-existing tectonic shear planes along the mudstone and sandstone bedding interfaces in similar geological terrain.
\end{abstract}

Keywords: case studies, earthworks, landslides, weathered mudstone, sandstone

In recent years, China has expanded its national expressway system. The rapid construction of national expressways in the southwestern region of China has taken place in areas with high mountains and deep river valleys. Construction in this terrain has created many cut and fill slopes and, not surprisingly, landslides are a common phenomenon during and after construction. Although considerable work has been carried out on slope stabilization and landslip prevention works, little has been published in the English literature.

This paper records a major landslide event during construction of a national expressway in the Chongqing region of southwestern China. The Yuqian Expressway (Phase I) is some $88 \mathrm{~km}$ long and runs from north to south in the Chongqing region to Guizhou Province (Fig. 1). It traverses mountaneous and hilly terrain with numerous rivers, steep slopes and deep valleys (Fig. 2). The total length of bridges and tunnels exceeds $14 \mathrm{~km}$. Earthworks including excavation and fill were carried out along a total length of about $74 \mathrm{~km}$ of the expressway.

According to the original design, the volume of earthworks was estimated at about $3.3 \mathrm{Mm}^{3}$. The cost of earthworks represented about $15 \%$ of the total construction budget. Due to the constraints of natural slopes and existing facilities, numerous high and steep cut and fill slopes were required. Stability (both short-term and long-term) of those high and steep man-made slopes proved a considerable challenge for the design and construction of the expressway (Yue et al. 2001).

\section{The landslide event}

In the afternoon of 27 April 1999, a major landslide occurred in a cut slope during the construction of the Yuqian National Expressway (Figs. 3 to 7). The landslide of unusual geometry, released an estimated $15,000 \mathrm{~m}^{3}$ of soil and rock from the hillside and produced a rough and undulating post-slide topography. The failed soil and rock block slipped, diagonally out of the cut slope, by about 2 to $7 \mathrm{~m}$ along a basal plane and created an open gap across the hillside. The open gap measured $53 \mathrm{~m}$ long, by 2 to $7 \mathrm{~m}$ wide and some 6 to $8 \mathrm{~m}$ high. It formed both a backscar and a release plane. The landslide debris travelled $13 \mathrm{~m}$ from the toe of the cut slope onto the platform for the road subgrade (Fig. 3). Highway construction ceased while investigations were carried out at the site.

\section{General site conditions}

\section{Geology}

The Yuqian National Expressway traverses mainly sedimentary mudstone and sandstone of Middle Jurassic age (Lee et al. 1999). The Yanshan tectonic upward movements during the Cretaceous period produced a series of NE to NNE trending non-symmetric folds in the strata. Figure 8 illustrates a typical profile of the geology in the region.

At the landslide site, local geology comprises a thin mantle of superficial Quaternary deposits overlying 


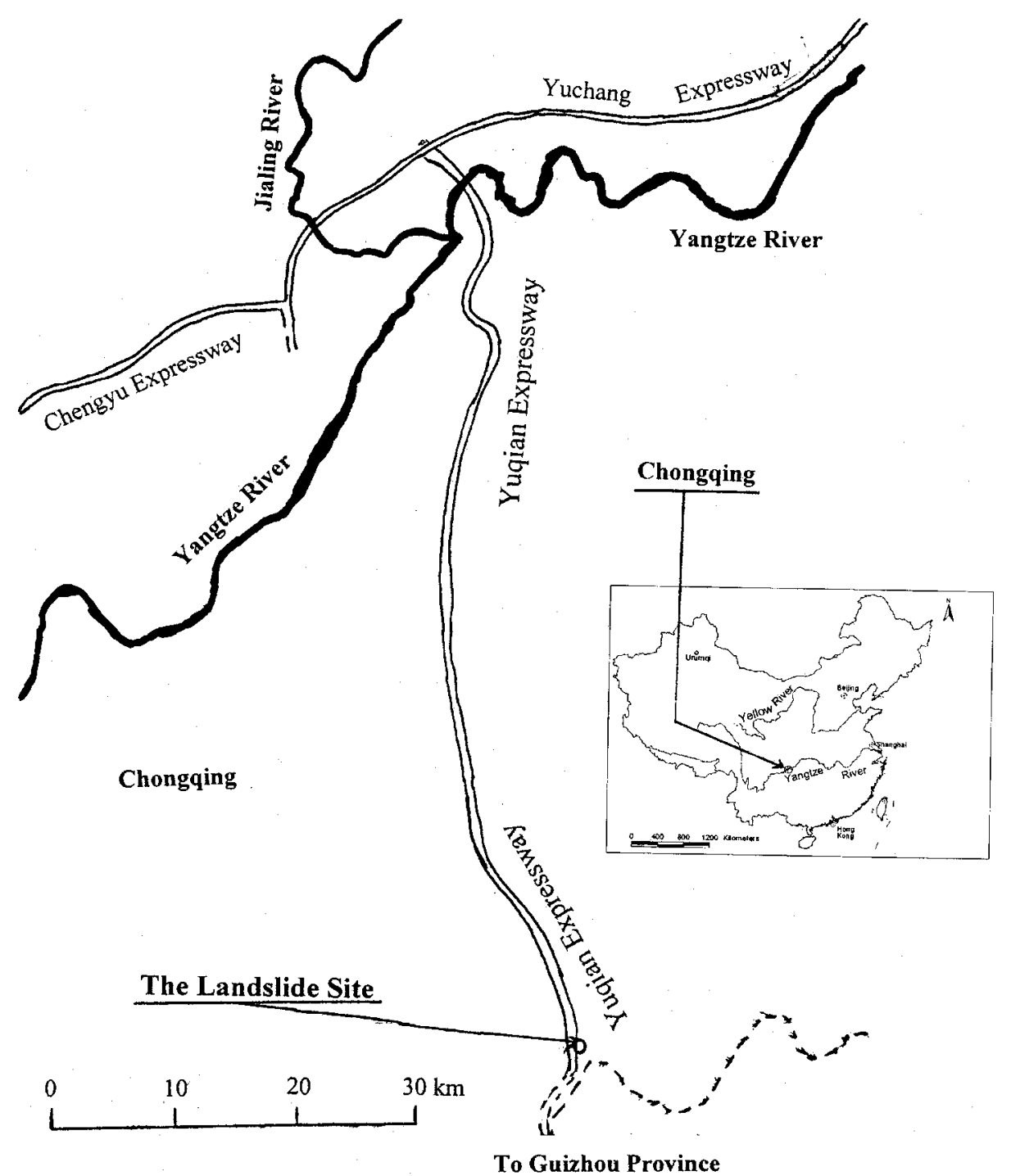

Fig. 1. Location of the landslide site on the Yuqian expressway construction in Chongqing, southwestern China.

highly weathered mudstone and moderately weathered sandstone. The hillside slopes have gentle slope angles and are thinly vegetated. The surficial deposits vary up to $2 \mathrm{~m}$ thick and mudstone stratum ranges from up to $15 \mathrm{~m}$ thick. Bedding dips at $24^{\circ}$ toward NW $\left(345^{\circ}\right)$

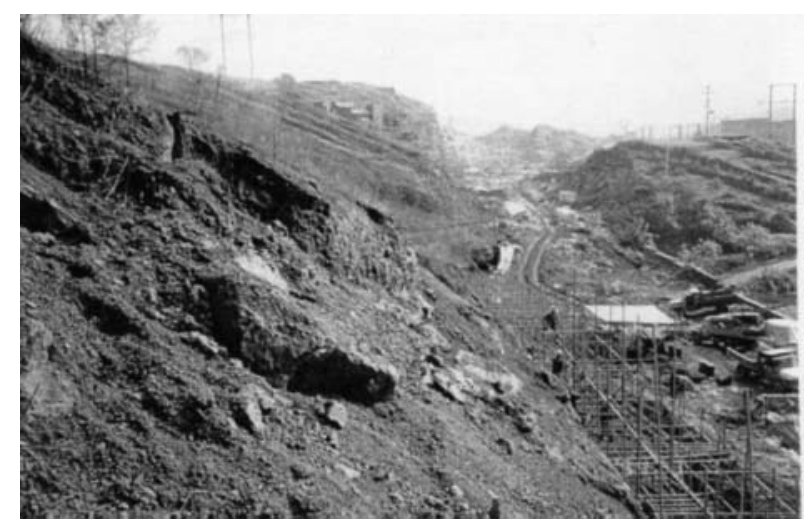

Fig. 2. Site photograph illustrating the general hilly terrain where the Yuqian National Expressway was being constructed. and the cut slope dips steeply toward NW $\left(323^{\circ}\right)$. Consequently bedding planes daylight on the cut slope face.

\section{Soil and rock properties}

Site investigation and laboratory testing indicated that the surficial deposits and the intact weathered mudstone and sandstone have density and shear strength values as listed in Table 1 (after Lee et al. 1999). The shear strength values were obtained from direct shear and triaxial tests. Table 2 lists some typical property values for clayey soils in weak seams and bedding interfaces. From these values it is apparent that the soils in the weak seams and bedding interfaces have low shear strength values and much lower residual shear strength values.

The mudstone appears highly sensitive to weathering and quickly swells and degrades once it encounters water. Under the atmospheric pressure condition, soil 


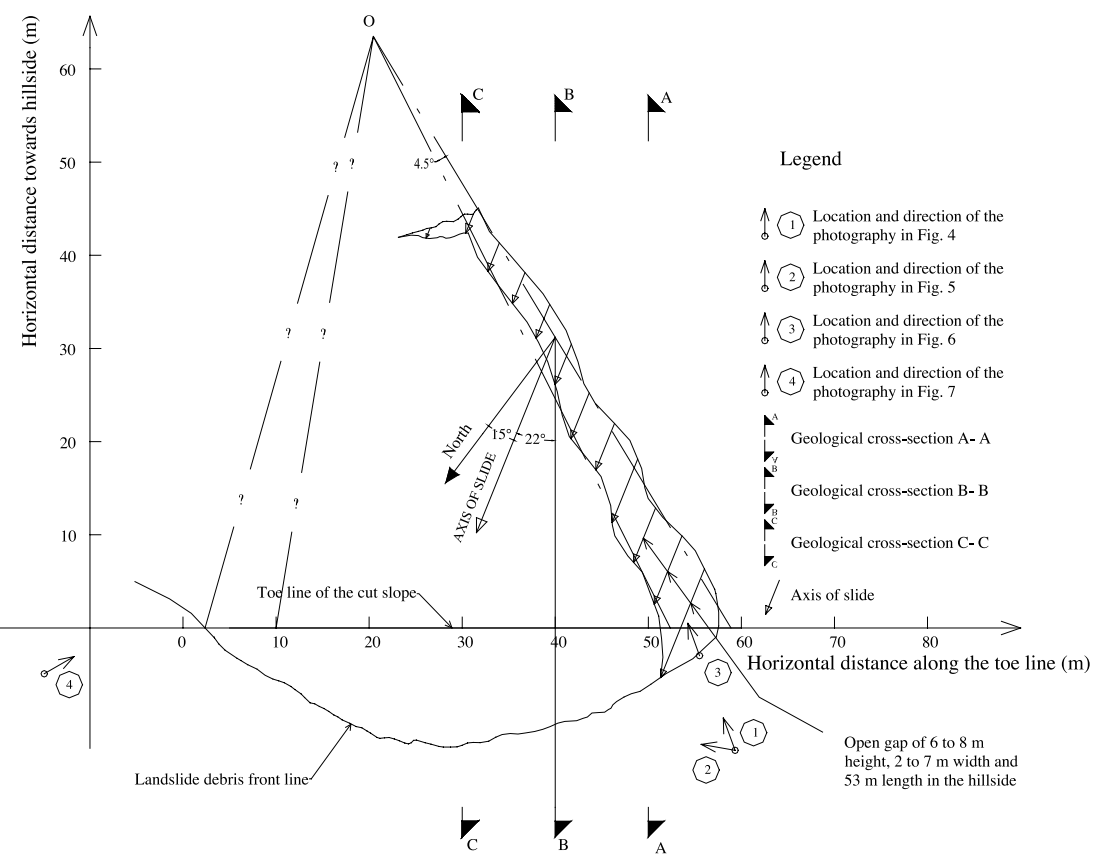

Fig. 3. Location plan illustrating the direction and extent of the landslide movement and the locations of the site photographs and geological cross-sections.

laboratory results indicated that the weathered mudstone could have a volume increase of as much as 20 to $110 \%$ once it was saturated with water. Furthermore, a majority of the surficial deposits are silty clay and clay soils derived from the completely weathered mudstone.

\section{Rainfall}

The expressway route site has a mid-latitude continental climate. Temperature ranges from 2 to $42^{\circ} \mathrm{C}$ with an annual average of $18^{\circ} \mathrm{C}$. Annual rainfall is about $975 \mathrm{~mm}$ to $1301 \mathrm{~mm}$. Rainfalls in spring, summer, autumn and winter are about 19 to $30 \%, 38$ to $51 \%, 23$ to $28 \%$ and 5 to $6 \%$ of the annual rainfall, respectively. The maximum record of daily rainfall is about $193 \mathrm{~mm}$.

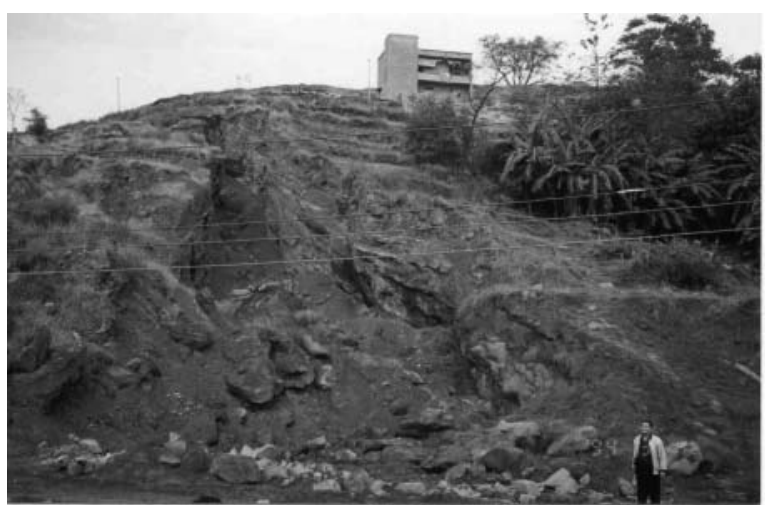

Fig. 4. The open gap and vertical and undulating tension cracks associated with the plane slide during construction of a national expressway in southeastern China, looking east. The open gap measured 6 to $8 \mathrm{~m}$ high, by 2 to $7 \mathrm{~m}$ wide and $53 \mathrm{~m}$ long in weathered mudstone overlying sandstone.
Heavy rainfalls in the summer can cause flooding in valleys in the hilly terrains. The groundwater table is usually at depth. Due to rainfall, this groundwater table could rise to the ground surface in local areas. Transient perched groundwater tables could be formed in the quaternary deposits and mudstone above the sandstone.

\section{Conditions before the landslide}

Construction of the Yuqian Expressway (Phase I) commenced in November 1997. At the landslide site slope excavation for the highway commenced in July 1998. By end of March 1999, excavation of the hillside slopes reached the road subgrade level. It was formed in a spur of the hillside and no provision existed for stabilization

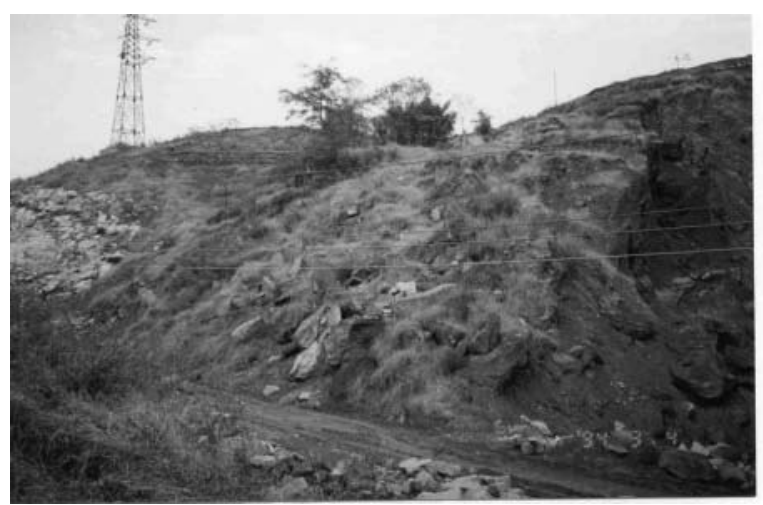

Fig. 5. The landslide debris comprising mainly weathered mudstone that travelled about $13 \mathrm{~m}$ onto the platform for the road subgrade, looking NE. Thick sandstone can be seen in an adjacent cut slope below the transmission tower. 


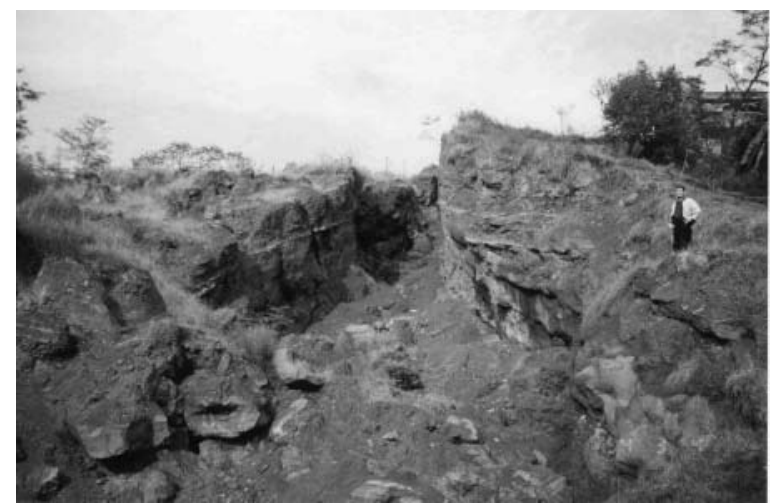

Fig. 6. A close view of the open gap and vertical and undulating tension cracks in the weathering mudstone with monoclinal beddings, looking east. Seepage from the bedding planes of the weathered mudstone is visible.

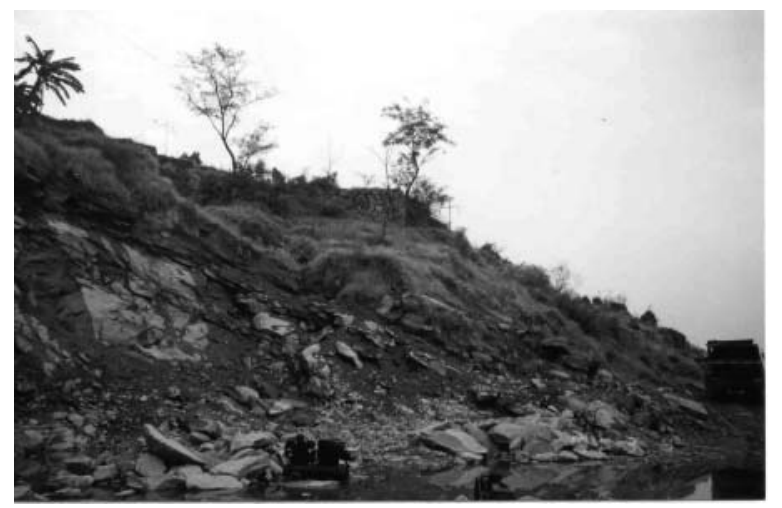

Fig. 7. A side view of the landslide debris comprising mainly weathered mudstone, looking south. Thick sandstone can be seen underlying the deformed weathered mudstone, and seepage from the contact bedding interface between the weathered mudstone and the sandstone is also visible. measures. Ground investigations at the site were limited to engineering geological mapping along the route prior to the excavation works.

The cut slope was about $55 \mathrm{~m}$ long and up to $25 \mathrm{~m}$ high. It had one or two batters. The lower batter was $10 \mathrm{~m}$ high and was inclined at $63.4^{\circ}$ (i.e. a slope gradient 1(H):2(V)). The upper batter had variable heights and a slope angle of $53.1^{\circ}$ (i.e. a slope gradient $4(\mathrm{H}): 3(\mathrm{~V})$ ). The berm between the lower and upper batters was $1 \mathrm{~m}$ wide. Figures $9,10 \& 11$ illustrate three geological profiles of the cut slope and the upper hillside slope before and after the landslide. The positions of the cross-sections are depicted in Figure 3.

Site investigation revealed that the sliding basal plane was the upper bedding surface of the thick sandstone unit that underlies the thick weathered mudstone. The sandstone surface was exposed on the upper hillside adjacent to the two-storey house shown in Figure 4. The thick sandstone might have acted as an impervious or relatively impermeable bottom layer that led to the formation of a perched ground water table in the weathered mudstone above, as evidenced by the water seeping out of the bedding interface in Figure 7. The thick sandstone strata adjacent to the landslide site can also be observed in Figures 5 \& 7.

In early April 1999, following excavation of the steep cut slope in the weathered mudstone, several vertical tension cracks appeared in the upper hillside slope. As a result, a farmer's house, originally situated on the slope had to be demolished and relocated. The cut slope eventually slipped down in the afternoon of April 27, 1999 after continuous rainfall for several days.

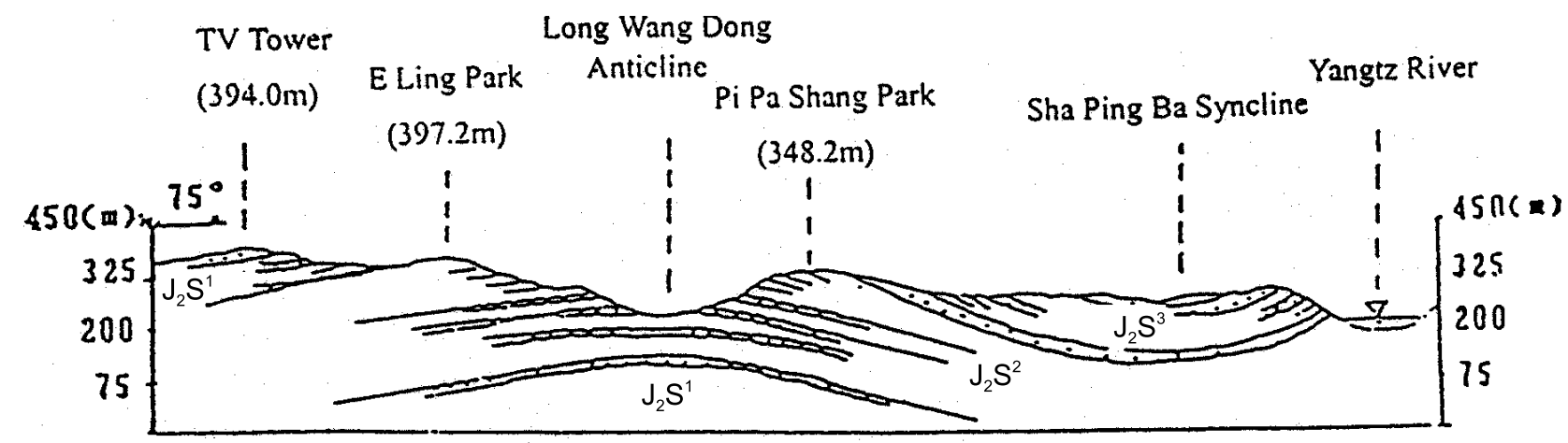

Fig. 8. Typical profile of geology and fold geological structure in Chongqing $\left(\mathrm{J}_{2} \mathrm{~S}^{1}=\right.$ Lower Shang-Sha-Xi-Miao Formation of the Middle Jurassic; $\mathrm{J}_{2} \mathrm{~S}^{2}=$ Middle Shang-Sha-Xi-Miao Formation of the Middle Jurassic; $\mathrm{J}_{2} \mathrm{~S}^{3}=$ Upper Shang-Sha-Xi-Miao Formation of the Middle Jurassic).

Table 1. Typical values for density and shear strength of soil and weathered intact rocks in Chongqing region.

\begin{tabular}{lcccc}
\hline & Dry density $\left(\mathrm{kN} / \mathrm{m}^{3}\right)$ & In-situ density $\left(\mathrm{kN} / \mathrm{m}^{3}\right)$ & Cohesion $\left(\mathrm{kN} / \mathrm{m}^{2}\right)$ & Frictional angle \\
\hline Surficial deposit (silty clay and clay) & $15.4 \sim 17.5$ & $19.5 \sim 20.5$ & $19 \sim 46$ & $10 \sim 22^{0}$ \\
Weathered intact mudstone & $22.2 \sim 25.3$ & $24.0 \sim 25.8$ & $90 \sim 1370$ & $25 \sim 30^{\circ}$ \\
Weathered intact sandstone & $23.7 \sim 24.3$ & $24.7 \sim 25.5$ & $600 \sim 3170$ & $33 \sim 45^{\circ}$ \\
\hline
\end{tabular}


Table 2. Typical values for clayey soils in weak zones and bedding interfaces in Chongqing region.

\begin{tabular}{lccccccc}
\hline $\begin{array}{l}\text { Water content } \\
(\%)\end{array}$ & $\begin{array}{c}\text { In-situ unit weight } \\
\left(\mathrm{kN} / \mathrm{m}^{3}\right)\end{array}$ & $\begin{array}{c}\text { Specific } \\
\text { gravity }\end{array}$ & $\begin{array}{c}\text { Liquid limit } \\
(\%)\end{array}$ & $\begin{array}{c}\text { Plastic limit } \\
(\%)\end{array}$ & $\begin{array}{c}\text { Plastic } \\
\text { index }\end{array}$ & $\begin{array}{c}\text { Cohesion [residual] } \\
(\mathrm{kPa})\end{array}$ & $\begin{array}{c}\text { Frictional angle } \\
{[\text { residual] }(\mathrm{degree})}\end{array}$ \\
\hline 20 & 21 & 2.7 & 29 & 18 & 11 & $39[18]$ & $24[11]$ \\
\hline
\end{tabular}

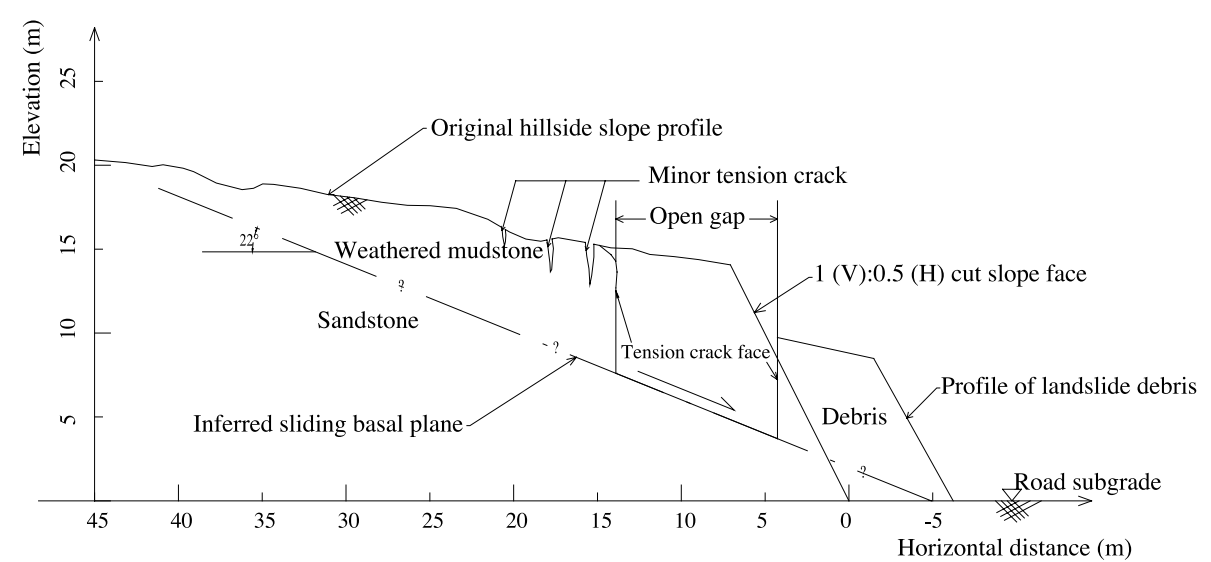

Fig. 9. Geological cross-section A-A.

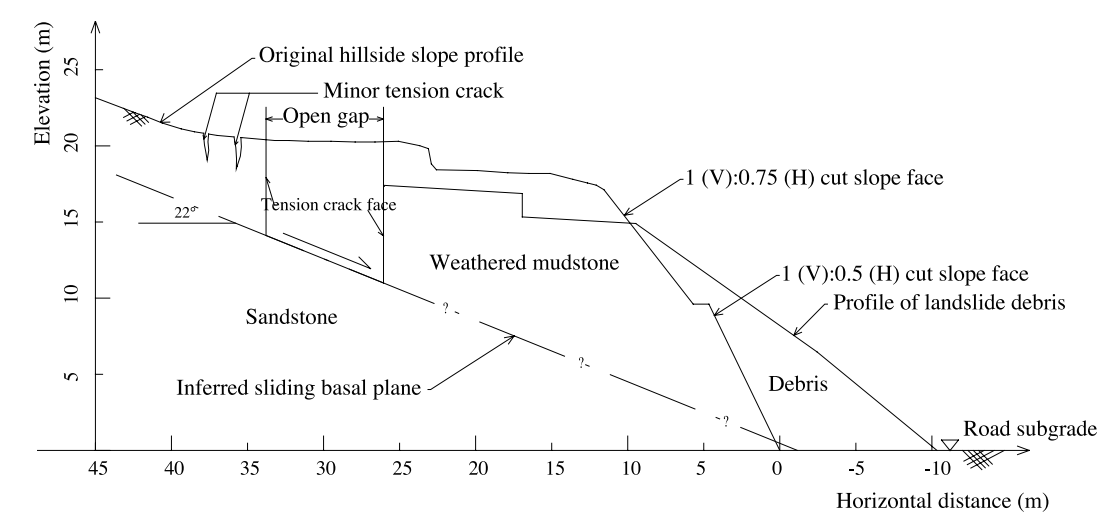

Fig. 10. Geological cross-section B-B.

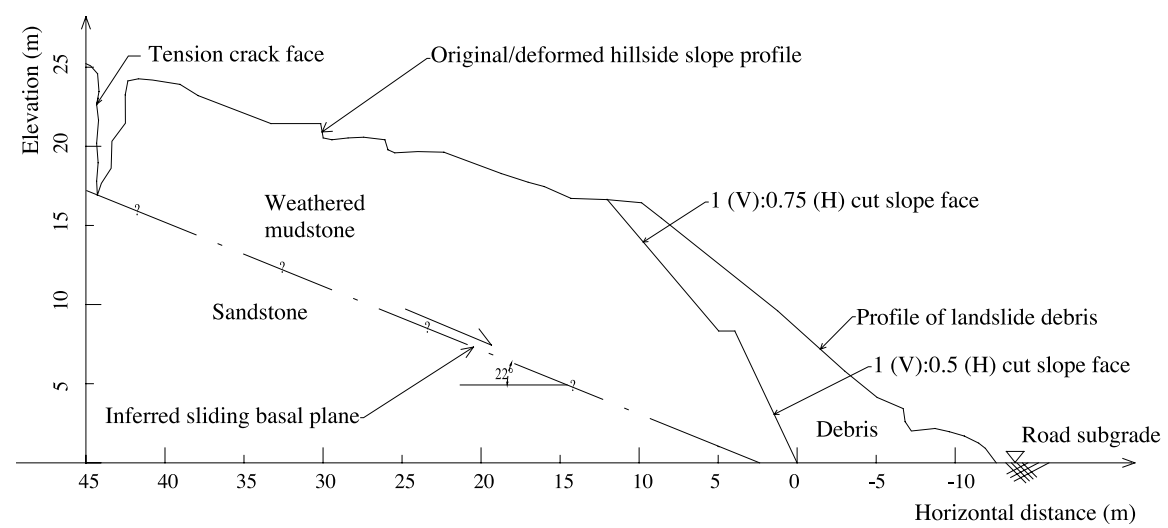

Fig. 11. Geological cross-section $\mathrm{C}-\mathrm{C}$.

The rainfall in March and April 1999 recorded with a rain gauge at about $1.3 \mathrm{~km}$ west of the landslide site is summarized in Table 3. From the rainfall records, it can be inferred that the rainfall during March and April 1999 had some influence on the initiation and propagation of tension cracks in the hillside slope above the newly formed cut slope. However, the rainfall appears light compared to the maximum daily rainfall of $193 \mathrm{~mm}$ in the region. And so may not be the principal factor triggering the landslide. 
Table 3. Rainfall record during March and April, 1999 near the landslide site.

\begin{tabular}{llr}
\hline Rainfall period & \multicolumn{1}{c}{ Raining date } & Sub-total rainfall (mm) \\
\hline March 1 to March 10, 1999 & March 7, 8, 9 and 10 & 30 \\
March 11 to March 20, 1999 & March 19 & 9 \\
March 21 to March 31, 1999 & March 27 & 15 \\
April 1 to April 10, 1999 & April 1 and 2 & 20 \\
April 11 to April 20,1999 & April 14 and 16 & 15 \\
April 21 to April 30,1999 & April 24, 25, 26 and 27 & 80 \\
\hline
\end{tabular}

\section{Direction of the landslide movement}

Figure 3 provides a plan view of the direction and extent of the landslide movement. The landslide is a typical planar failure. The failed block of weathered mudstone slipped down following the dip direction of the sandstone basal plane. The direction of the slide had an angle of $22^{\circ}$ with the dip direction of the cut slope face. As a result, the open gap in the hillside had its widest portion at between 50 and $60 \mathrm{~m}$ of the local horizontal distance along the toe line (Fig. 3). This open space became progressively narrower towards the upper hillside. The open space has the two vertical tension crack surfaces as its boundaries (see Figs $9 \& 10$ ). The open space has a narrow wedge-shaped configuration in plan. The wedge has an angle of $4.5^{\circ}$ with its tip located at the point $\mathrm{O}$, as shown in Figure 3.

Interestingly, the open space discontinues at the position where it intersects with the line of geological section $\mathrm{C}-\mathrm{C}$. At the cut slope toe of the section $\mathrm{C}-\mathrm{C}$, the sandstone sliding basal plane was about $0.5 \mathrm{~m}$ below the excavated road platform and not exposed on the cut slope surface. The unexcavated weathered mudstone above the basal plane and in front of the cut slope could offer some resistance to the landslide. The open space therefore discontinues and terminates at the upper region of the section $\mathrm{C}-\mathrm{C}$.

\section{Stability analysis}

The two-dimensional model in Hoek \& Bray (1981) for plane failure was used to analyse the landslide described above. The factor of safety (FOS) of the cut slope, with a tension crack in its upper hillside surface, can be expressed as follows:

$$
F O S=\frac{c A+\left(W \cos \psi_{p}-U-V \sin \psi_{p}\right) \tan (\varphi)}{W \sin \psi_{p}+V \cos \psi_{p}}
$$

where

$c=$ the total cohesion of the weathered mudstone $\left(\mathrm{kN} / \mathrm{m}^{2}\right)$

$\varphi=$ the total frictional angle of the weathered mudstone (degree) $\psi_{p}=$ the total frictional angle of the weathered mudstone (degree)

$A=$ the area of the sliding basal plane with a unit width $\left(\mathrm{m}^{2}\right)$

$\mathrm{W}=$ the total weight of the sliding soil and rock block with a unit width $(\mathrm{kN})$

$V=$ the total pressure of water in the tension crack with a unit width $(\mathrm{kN})$

$U=$ the total pressure of water acting upward on the sliding block on the sliding basal plane with a unit width $(\mathrm{kN})$.

For a tension crack filled with water to a height $Z_{w}$, the $V$ and $U$ can be calculated using following equation.

$$
V=\frac{1}{2} \gamma_{w} Z_{w}^{2}
$$

and

$$
U=\frac{1}{2} \gamma_{w} Z_{w} A
$$

where $\gamma_{w}$ is the unit weight of water $\left(9.81 \mathrm{kN} / \mathrm{m}^{3}\right)$.

For simplicity, the geological sections A-A and B-B are used in the stability analysis to verify if the causes postulated above are theoretically admissible although they do not fall along the direction of sliding. The results of the slope stability analysis are presented in Figure 12 for a plane failure in the cut slope. In the analysis, the factor of safety was assumed to be unity. The heights of the perched water table in the tension cracks $\left(Z_{w}\right)$ were assumed to be $0,1,3$ and $5 \mathrm{~m}$, respectively. Figure 12 illustrates the relationship between the total cohesion $c$ and the total frictional angle $\varphi$ under the conditions of a FOS of unity and the perched groundwater tables. The following can be deduced from Figure 12:

- If both Sections A-A and B-B have a FOS of unity and the same $Z_{w}$, the values of $(c, \varphi)$ are equal to $(0$, $\left.22^{\circ}\right),\left(3,21.8^{\circ}\right),\left(15,20^{\circ}\right)$ and $\left(33,16^{\circ}\right)$, for $Z_{w}$ equal to $0,1,3$ and $5 \mathrm{~m}$, respectively.

- If Section $\mathrm{A}-\mathrm{A}$ is dry (i.e., $Z_{w}=0$ ) while Section $\mathrm{B}-\mathrm{B}$ is not dry (i.e., $Z_{w} \neq 0$ ), it is not possible for both Sections A-A and B-B to have a FOS of unity under the same values of $(c, \varphi)$. 


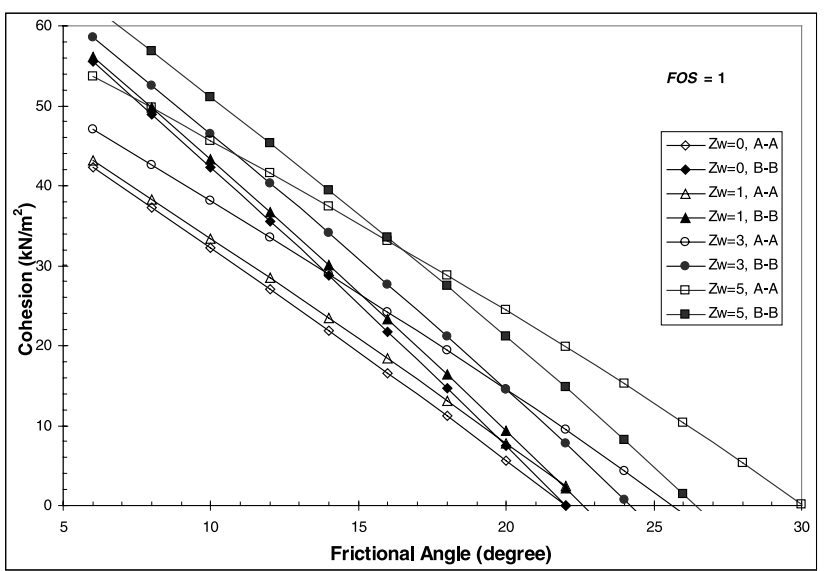

Fig. 12. Relationship between the cohesion and the frictional angle of the weathered mudstone for sliding along the mudstone and sandstone bedding interface and for a factor of safety (FOS) of unity, with reference to the sliding blocks in Section A-A and B-B under different perched groundwater table $\left(Z_{\mathrm{w}}\right)$ in the tension cracks.

- If $Z_{w}$ in Section $\mathrm{A}-\mathrm{A}$ is less than that in Section $\mathrm{B}-\mathrm{B}$, it is not possible for the two sections to have a FOS of unity under the same values of $(c, \varphi)$.

- If $Z_{w}$ in Section $\mathrm{A}-\mathrm{A}$ is greater than that in Section $\mathrm{B}-\mathrm{B}$, it is possible for the two sections to have a FOS of unity under the same values of $(c, \varphi)$.

- The possible range of $(c, \varphi)$ for the two sections to have a FOS of unity is from $\left(0,22^{\circ}\right)$ to $\left(52,7^{\circ}\right)$.

From the above stability analysis, it can be deduced that the possible range of $(c, \varphi)$ for the landslide to occur in the mudstone is much lower than that of the intact weathered mudstone in Table 1 , but is close to those of the surficial deposits (silty clay and clay soils) in Table 1 and the clay soils at bedding interfaces in Table 2. This may indicate that the soil forming the incompetent weathered mudstone and the competent sandstone bedding interface had low shear strengths similar to those in Table 2. Such low strength bedding interface soil may indicate that the incompetent mudstone and competent sandstone layers had experienced bedding shear due to folding tectonic movements. (Tanner 1989; Hutchinson 1988, 1995; Gordon et al. 1996; Scott et al. 1997). The bedding interface of the mudstone and sandstone could be a pre-existing tectonic shear plane. The shear strength of the interface soil can reach the residual strength of the weathered mudstone in Table 2. Hence, failure can occur without unusually high water pressure. The presence of vertical tension cracks in the hillside slope before the major landslide may also indicate that progressive failures had occurred along the bedding interface at ordinary rainfall conditions.

Furthermore, the above analysis also indicates that the presence of a perched water table was important for the landslide to occur. The perched water table in Section A-A may be higher than that in Section B-B, which is reasonable since the tension crack in Section A-A was lower than that in Section B-B.

\section{Causes of the landslide}

Based on the above information and associated analyses, the main causes of the landslide can be postulated as follows:

- Unsupported high and steep cutting in weathered mudstone.

- An exposed bedding interface between the incompetent weathered mudstone and the competent sandstone and daylighting within the cut slope.

- The mudstone and sandstone bedding interface is a pre-existing tectonic shear plane of low shear strength.

- Possible presence of a groundwater table in the weathered mudstone perched on the relative impermeable sandstone bedding surface and rainwater accumulated in the vertical tension cracks during the rainfall of the later April, 1999.

\section{Conclusions}

This landslide case study demonstrates the importance of engineering geological mapping during or immediately after the formation of a new cut slope. Such detailed mapping would have revealed the existence of a major daylighting bedding interface between the mudstone and sandstone in the new cut slope. Unfortunately, such work was not implemented even though tensile cracks had appeared in the hillside slope above the cutting. As a result, the major landslide occurred about one month after the cut slope was formed.

It is also equally important to recognize the preexisting tectonic shear planes along the mudstone and sandstone bedding interfaces in the Chongqing region of folding tectonic movements. The influence of bedding shears would reduce the shear strength of the incompetent weathered mudstone to a very low level.

A large number of man-made cut slopes have been constructed along the expressway and their failure has led to significant additional costs in expressway construction. They could also incur additional costs and significant consequence in the long term. Further investigations on selected and typical landslides have been suggested in order to learn lessons and identify optimum solutions.

Acknowledgements. Financial support from the Hong Kong Jockey Club Charities Trust and the Research Grants Council of Hong Kong are gratefully acknowledged. The authors would also like to thank the reviewers and the editor whose peer review comments have enhanced the paper. 


\section{References}

Gordon, T., Scott, M.J. \& Statham, I. 1996. The identification of bedding shears and their implications for road cutting design and construction. In: BARLA, G. (ed.) Eurock 96 - ISRM International Symposium, 1. Balkema, 597-603.

Hoek, E. \& Bray, J. 1981. Rock Slope Engineering, 3rd edn. The Institute of Mining and Metallurgy, London.

Hutchinson, J.N. 1988. Morphological and Geotechnical parameters of landslides in relation to geology and hydrogeology. Proceedings of the 5th International Symposium on Landslides, 1, 3-35.

Hutchinson, J.N. 1995. The significance of tectonically produced bedding shears. Proceedings of the 11th European Conference of Soil Mechanics and Foundation Engineering, 4, 59-67.

Lee, C.F., Law, K.T., Wang, Z.Q. \& Wang, M. 1999. Comparison of Landslip Hazard Mitigation Methodology
Between Hong Kong and Chongqing. Technical Report of the Jockey Club Research and Information Centre for Landslip Prevention and Land Development. Department of Civil Engineering, The University of Hong Kong, Hong Kong, China.

Scott, M.J., Gordon, T., Statham, I. \& Nichol, D. 1997. Rock Anchor stabilisation of bedding plane shear failures on the A55, Rhuallt Hill. In: LitTLEJohn, G.S. (ed.) Ground Anchorages and Anchored Structures. Thomas Telford, London, 281-291.

TANNER, P.W.G. 1989. The flexural slip mechanism. Journal of Structure Geology, 11, 635-655.

Yue, Z.Q., Lee, C.F. \& Pan, X.D. 2001. Landslides and Stabilization Measures during Construction of a National Expressway in Chongqing, Southwestern China. Proceedings of International Conference on Landslides: Causes, Impacts and Countermeasures. Davos, Switzerland, 625-633. 